$316.722(540)$

https://doi.org/10.18485/kud_kp.2018.ch9

\author{
проф. др Александар Петровић \\ Универзитет у Београду \\ Филолошки факултет
}

\title{
ЕГЗОДУС НА КРОВУ
}

Индијска железница као екстатичка метафора слободе

\section{Сажетак}

Железница која зацртаним колосеком иде ка коначном циљу један је од симбола моћи просвећене историје. Међутим у индијској култури железница поприма значења која надилазе представу брзог напредовања и освајања циља. Слика претрпаних композиција је уобичајена химера о индијским возовима у коју су као у медијску паучину ухваћене опште предрасуде. Ти призори мноштва људи на крововима, док једнак број у гроздовима виси на боковима заиста постоје, али они су махом део неке од безбројних светковина када се становништво побуђено слива из околине у средиште прославе. Како модерни човек одавно нема своје дионизијске свечаности и сатурналије, већ једино сурогате друштва спектакла, он то не може да осети и та му се слобода чини као пуки проблем транспорта. Реч је о

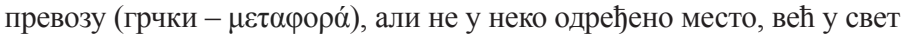
слободе. Железница на тај начин носи екстатичну поруку преласка.

Кључне речи: индијска железница. слобода, метафора, екстаза, парна машина.

Железница је људска прича о простору и времену испричана у гвозденом добу покренутом воденом паром под притиском. Настаје крајем XVIII века када је просвеће- 
ним подухватом енциклопедиста и њихових настављача започело путовање кроз време које је названо историјом. Стара грчка реч нову поруку путовања кроз време која није имала много заједничког с античким искуством. Јавила се идеја да историју треба стварати, да њоме треба управљати тако што he се схватити њени принципи. Историја која се пре просвећеног тријумфа Разума догађала спонтано, после победе револуције требало је да буде свесно произведена. Она је уз безбројне замене теза и травестије прави производ револуције. Стара историја одбачена је као превазиђена да би се користила само као фосилизовани угаљ који је сагоревањем требало да храни парну машину модернизације и напретка. Само је корак био потребан да би се револуционарна власт над историјом првих година XIX века технолошки објавила као парна машина високог притиска која ће се брзо транспоновати у локомотиву која ће вући, како се то лепо каже, железничку композицију, музику новог времена. Развој од Њукоменове парне машине атмосферског притиска до машине високог притиска Ричарда Третвика довољно је јасно показивао да притисак у друштву расте. Општије речено, развој технологије је мера притиска на основне ћелије друштва. ${ }^{1}$

1 Друштво може да издржи само ограничен развој технологије. Када он пређе границу, друштво се неминовно распада под притиском које не може да издржи. Сликовито речено, може се направити авион који иде четири пут брже од звука, али не и пилот који то може да издржи. Логично је да онда пилота треба заменити аутоматским управљањем, новом генерацијом технологије, али то доводи до истог резултата елиминисања пилота, као и целог система образовања који га припрема. Зато се данас и мења систем образовања у целом свету јер друштво више не може да издржи повећане притиске великих брзина. Порука нових реформи образовања је да је човек заправо непотребан, односно да друштво не може да одбрани себе пред све насилнијим захтевима технологије. Једини излаз из тога је поставити границе технолошког „развоја“ који је заправо боље звати технолошки раздор. 
Железница је постала веродостојна слика власти над историјом која се брзо ширила на све четири стране овог света. Револуционарно друштво грабило је напред у непрекидној грозници откривања природе и освајања земаља и народа што је најбољи израз добило у парној машини, паду екстазе у технологију. Узалуд су се урођеници свих боја својим ритуалима, кишом крхких стрелица и ломним копљима очајно борили против гвозденог просветитељства које је заробило екстазу и овладало механиком историје. Њихова борба била је уклета на пропаст јер нису имали историју, јер је железница неумитно продирала у живот, уклапала га у технолошки склоп и убрзавала ход историје да би произвела човека као путника. Свуда се може стићи, само треба имати тачан ред вожње, резервисано место у возу и знати ко је машиновођа, а ко шеф станице. И не треба каснити да воз не би отишао у будућност историје без путника довољно увереног у немоћ да сам било где стигне. Железница је исцртавала пут који је без размишљања требало следити. Зато се и говори о локомотиви развоја или кашњењу на воз промена. Просветитељство је тако постало фабрика историје која је на основу великог плана просветитеља требало да извлачи профит из кретања ка успутном или крајњем циљу. Погон се до данас толико замахао да су неки забринути мислиоци срачунали да у до сада произведеној европској историји има бар 300 година вишка догађаја који се не могу сместити у познату временску скалу година које су небеском механиком ограничене на приближно 365 дана. И небеска механика је тесна захукталој железничкој композицији. ${ }^{2}$

\footnotetext{
2 Вишак година говори о стварању друге историје које је узело маха у барокној противреформацији када је раскошним домишљањима митских сцена и измишљањима „историјских“ докумената требало усправити протестантизмом пољуљану вертикалу римске власти. У бароку слике излазе из рамова и архитектонских оквира и разливају се унутар сакралних простора да би показале снагу нове виртуелне стварности, као што се и традиционални летописи изливају из корита
} 
Живот сведен на ред вожње и железница као симбол кретања које не може скренути с постављеног колосека сасвим је добар симбол просвећеног историјског подухвата. Али том мнењу насупрот стоји доживљај индијске железнице који надилази представу о пуком средству усмерене промене историјског места у простору и времену. Историја постоји и у Индији, али нема просветитељску гвоздену обавезност: тако је било и никако другачије, само јеретици не верују да је тако било и имају неке другачије погледе на монотеизам историје Ако верујете да је било другачије, за вас нема места у возу. Историја је за просветитеље наука и по томе веома подсећају на јунака Андрићеве приче Злостављање који психички мучи своју жену причајући јој сваке ноћи о својој памети, успесима и достигнућима. „Аница зна добро ту причу“, вели Андрић, ,али она је сваки пут прати, и проверава у свом јаком памћењу да ли четкар штогод мења, одузима или додаје. И зачудо, прича је сваки пут до ситница верна и једнака, како само причање измишљених доживљаја може да буде.“3 Индија има мноштво историја, већ и због тога што у хиндуизму има неколико милиона богова. Ко ће све њих уклопити у једну композицију железничке историје?

Гхарипури, „град прочишћења“, низ храмова уклесаних у стени, посвећених непрегледном скупу богова, према браманским списима изградили су пре 374.000 година синови Пандуа који су учествовали у рату династија Сунца и Месеца о коме говори Махабхарайа. Међутим, према европској науци град је подигнут тек у VII веку. То се ипак не може ставити на исти колосек. Чак ни британска Источ-

истине писањем различитих „новопронађених“ списа из даље „прошлости“ који треба да успоставе и одбране римски монотеизам историје. То је више него ишта друго припремило просвећени енциклопедизам, у основи барокни поглед на науку и прошлост.

3 Иво Андрић, Злосииављање, „Приче о особењацима и малим људима“. Београд: Лагуна, стр. 79. Захваљујем се др Данку Камчевском који ми је скренуо пажњу на ову Андрићеву приповетку. 
но - индијска компанија није то успела, јер толико богова није могуће оробити као људе којима је просвећена антропологија послужила теорију о небеској породици као одразу земаљске. Зато Индију железница није колонизовала иако је Источно - индијска компанија прву пругу пустила у погон још 16. априла 1853. Линија Бомбај - Тхана отворена је уз 22 почасна плотуна, јер су просвећени Британци веровали да тиме дају знак за трку која ће довести до истих исхода као у западној Индији, како су тада звали Америку - општег уништења у име историјске композиције и њеног незауставивог хода захуктале модернизације. Међутим, нису били довољно опрезни да спрече да три локомотиве које су вукле композицију понесу имена коју су им дали домородци - назване су Синдх, Султан и Сахиб. Та персонализација машинског склопа скупо је коштала завојеваче - железница није обавила свој задатак као у Америци где су локомотиве биле безличне немани без имена које су сејале смрт међу бизонима и Индијанцима.

Индија није доживела исту судбину као Америка, јер је историја за њу била само један пут ништа битнији од других. Када кренемо на пут, некада се чини да смо прешли неко растојање, а некада да се нисмо макли с места. То су два вида путовања. И у једном и у другом виду крећемо се кроз време. Чак и да нигде не стигнемо, прохујало је време. И тешко нам је да разлучимо да ли нас је то време одвело негде у простору? Да ли Ахил који без даха јури корњачу негде стиже или нестаје у простору који се утварно раздваја док корњача, тако привидно спора, остаје недостижна? И да ли, како каже Гарсија Лорка, иако можда знамо пут, никада нећемо стићи у Кордобу? Путовање је основна чињеница људског искуства, јер троши оно што људима једино стоји на располагању, простор и време, који истовремено остају неухватљиви, недодирљиви и несхватљиви. Путеви су ту само да нас то подсете. Они су ватра у којој све гори да би се непрестано мењало и преображавало: путеви напред и назад, путеви горе и доле, путеви кружни и прави, сви 
испреплетени путеви. Сеобе тела и душа који не познају почетак нити ће икад сазнати крај. Путеви на којима ћемо с неверицом откривати властите трагове. Да ли је могуће да сам већ овде био? Колико пута сам овде био? Где идем, куда путујем, да ли је негде скривен путоказ?

Због оваквих мисли вреди напустити просвећену историју и отпутовати у Индију. Тамо оне долазе природно, као да једноставно негде чекају данима, годинама или миленијумима да би вас заскочиле у тренутку, без устезања, без преговора и без удварања предрасудама. Не можете их се спасти када их сретнете на прометном аутопуту у подножју Хималаја где тутње огромни камиони сви до једног сноликом декорацијом претворени у хиндуистичке или хришћанске храмове, са Кришном или Христом чија слика украшава прочеље њихових ветробрана. Боже, ово није могуће, прва је мисао, да је Бог толико близак. Немогуће је да Бог вози, тутњи аутопутевима, немогуће је да све време док окрећу точак самсаре сви ови возачи у сваком трену верују. Ако је то могуће, онда остали свет није могућ; ако то постоји, онда ми не постојимо. Зар није боље да просвећено верујемо да је то само декорација, празан ритуал? Али где они путују овако натоварени камењем, цементом, нафтом, циглама, поврћем, било чиме другим? Путују ли као и ми оптерећени својом историјом и очекивањем благостања на крају пута, зашто онда то не чине разумно као ми, већ од немани механичког превоза стварају храм, место поклоничког ходочашћа? Иду ли да би стигли или верују да су у сваком тренутку већ стигли без обзира где се налазе? Нема сумње да за њих исходиште није исто што и стизање. То је небитна појединост, крај историје, историјски циљ, сасвим неважан тренутак који наступа као крај песме, као постигнут циљ, као празнина, ништа више.

Без обзира на исход размишљања извесно је да ови друмски превозници довољно откривају да је само путовање храм, да је то прибежиште, да је разрешење онога што још није било. Хераклитова река у којој се не може два пута оку- 
пати је прави храм, оно што је непоновљиво, блистајућа јединственост која се не може копирати. Храм је смрт машине, а машина која уклето понавља је рушење храма. А то је тако одсудно помирено у машинама Индије којима човек по вољи богова управља тако што им удахњује душу да би оне само због тога, а не због горива којим се поје, крстариле путевима. За остатак света то је само машина, док је за Индију то нека гандхарва, Ганеша или Кришна који је само узео механичко тело. Зашто он то не би урадио? Каква граница га спречава да се оваплоти као механички аватар? Зар некада раније, на самом почетку, није био риба? Зар све, као код просветитеља, мора да буде ствар човека? Како ће се машина отети да не буде Он? Док у пролазу гледам лица иза ветробранског стакла у магновењу се срећем с њиховим очима и видим да ти возачи храмова - прости, непатворени, сирови, груби и сабрани у исти мах - то знају. Они то знају, верујем да то знају, осећам да доживљавају да су унутар Кришне, да он вози док се они држе за точак судбине, да он вози као што је управљао и Арџунином бојном запрегом преносећи му основна знања о животу и смрти, кружењу самсаре и ослобођењу из круга, утварности материје, сељењу вечног живота, кастама и њиховим дужностима. Могу ли и ја да посматрам свет њиховим очима? Шта они виде? Да ли су стигли? Куда идем?

Ова питања постављају се још снажније када просвећени путник у Индији дође у прилику да путује возом. Индијски возови су одличне израде, која започиње у овој земљи још 1895, тачни су у минут и сваки дан превезу тридесет милиона путника. Ако би закаснили који минут, или стигли раније, цео железнички систем који опслужује 1,2 милијарде становника неминовно би малу грешку великом множином кретања тако појачао да би се вероватно распао у току истог дана. А за њим би цела земља ефектом домина потонула у узбуркани хаос као што се некада догодило Атлантиди. ${ }^{4}$ Али не само да су тачни, већ су и

4 Можда је заправо проблем с превозом довео до пропасти Атлантиде? Ако не решите питање превоза, филозофски речено проблем 
сасвим удобни, масивни, климатизовани, особље увежбано и посвећено послу. Индијска железница је, упркос свим предрасудама које може да има европски путник, веома пријатељско средство путовања. Прво вас наравно збуни мноштво људи у великим чекаоницама које се ту осећа као код куће. Мање је ту ужурбаног комешања, а више смиреног чекања, породичног живота, друштвених игара, размене осмеха, дубоких снова, шареног карусела живота који је тако добро прекрио простор да се морате провлачити неком ивицом живота да бисте дошли негде. Наравно, они вас обесхрабрују својим изгледом неког ко је одавно стигао, било то овде или на неком другом месту где ће потом једнако стићи.

Када једном уђете у воз, врло брзо увидите и да је храна која су у њему служи добра, дневне новине бројне, на мноштву језика, од којих сам нажалост знао само колонијални енглески на коме се не може прочитати ништа битно. Енглески је језик путописа о народима који су махом уништени. Данас на њему у бројним документираним филмовима наратори најрадије говоре о свету који нестаје. Једно од општих места тих филмова, када је реч о Индији, јесу претрпани возови у којима мноштво путника нема своја места, већ су принуђени да седе на крову и да висе са страница возова. Ова слика је уобичајена химера о индијским железницама у коју су као у медијску паучину ухваћене опште предрасуде. Телевизијске серије и Хегелова филозофија историје учинили су је посве природним. Прешао сам многе хиљаде километара у Индији

промене, земља и људи су у великој невољи, чак и ако то не знају. Мора да су се и у Атлантиди појавили неки просвећени софисти, данас би се рекло реформатори, који су промену тумачили као историју, а онда тражили покретачке силе промене којима су хтели да овладају привидом. Као да промена има покретачке силе, као да промена сама није покретачка сила. У тој замени теза лежи замка свеопште пропасти. Можда ту вреба бездан који треба оправдати историјом. По томе као да се ипак неко с Атлантиде спасао да би продужио стару причу, није потонуо да бисмо сви наставили да тонемо. 
и нигде нисам видео такве сцене. Где су они нашли те возове? То ме је питање мучило јер нисам желео да свет гледам британским очима. Одговор ме је убрзо сам нашао јер се најбоља збирка одговора на све и свашта налази управо у Индији. Одговор је био фестивал Кумбх Мела који је највеће окупљање људи на нашем небеском телу. За два месеца у место Алахабад, на ушћу Ганге и Јамуне, дошло је 2013. године 120 (словима: $c \bar{u} о$ gваgесей) милиона људи да би се окупало у светој реци и тиме додирнуло кап бесмртности коју је некада давно из крчага случајно просуо бог Вишну. Не можемо а да не замишљамо железницу која све те људе у кратком времену треба да превезе. Логично је и да помислимо да у таквим околностима људи траже своје место не само у композицији већ и на њеним крововима.

Ипак преварили бисмо се да проблем капацитета то велико мноштво пење горе. Има нечега много битнијег што скривају засенчена лица возача у њиховим храмовима на друму. Они хрле Богу и не сумњају да и он њима долази у сусрет. Знају да ће га пре или касније срести на путу. И путници који су кренули да нађу митски суптилну невидљиву Сарасвати на ушћу Јамуне у Гангу, да ту потраже давни траг бесмртности, то исто знају. Природно је да их подилази нестрпљење док се приближавају, тешко је седети прикован иза прозора у гвозденом кавезу док је бесмртност свуда наоколо. И од нестрпљиве чежње, радосног ишчекивања, нестишљиве наде излазе и пењу се на кров. Ту је много пријатније, егзистенцијално удобније, јер ни места ни људи нису резервисани, ту су веће шансе за живот, за наслућивање протока смисла, изгледнија прилика да се тренутак спајања не пропусти. То осећање скаче као варница с једног на другог путника, електрицитет их побуђује и они морају да се покрену. Тако је и на свим другим свечаностима у Индији када се река, поплава људи из околних села и предела слива ка месту светковине. Људи постају вода, она река за коју Хераклит каже да 
је непоновљива, да се у њој не може два пута окупати. Воз постаје превозно средство, али за једно друго путовање. Не оно којим се мења место, а тренутак садашњости за трен никада дошле будућности, већ превозно средство којим се излази изван себе, јер Ахил никада неће стићи корњачу; као што је до сада никада није стигао, никада је

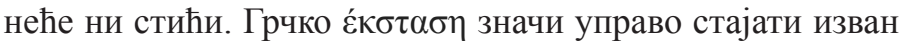
себе. Они напуштају себе, историјско, привидно ја, и постају Атман, спајају се у општу свест, велико неподељено Ja, које је вода, које је река, управо као она Ганга, која неухватљиво стреми самој себи. Тако постају свесни да и сами потичу од реке и да је она велика нит спајања која ce не може по вољи кидати као историја. Окупати се у Ганги значи очистити се од историје и путовати без терета привида. Возови тако постају екстатичко возило Атмана, превозници свести која долази до себе. Енглези наравно у томе виде само гужву, и одсуство резервације, која гарантује свакоме по једно место и ништа више. Они нису у стању да виде оно што се дешава јер то слепило је цена њиховог себичног и похлепног колонијализма који разазнаје и признаје само оно што се може отети, однети и сакрити од других. Они су кажњени већ самим тим што никада неће моћи да уђу у воз који преноси слободу.

Последица екстазе која се може осетити у индијским железницама је и да мртве ствари оживљавају. Када се погледа воз прекривен и украшен грозодвима људи, види се да је машини удахнута душа коју јој је одузела револуција. Заиста није могуће ићи на свету реку, прићи живој мајци која даје и узима живот седећи на резервисаним местима, одвојен својим малим ја од света и одсутно зурити у пејзаже који промичу. То и није путовање, већ његова супротност, туризам. Уместо тога, када се попну на кров путници већ у возу почињу светковину, обузима их усхићење у коме изгледају дивљи и затуцани. Међутим, само таквим проширивањем видика, на крову воза, или крову света, свеједно, путник долази у додир са бићем оног што треба 
да га прочисти, препороди и оживи. Ваздух је претходница воде, вода ватре, а ватра све враћа земљи. Ганга је већ присутна на крову воза, а ваздух који као река свуда струји наговештава њену близину тако да се руше границе у које је затворена душа, путници су опчињени и ослобођени свакодневне уљуљканости у привид да би осетили да их воз подиже изнад онога што их окружује. Они лагано излазе из свог тела док струја ваздуха, тако мало различита од водене струје, најављује близину Сарасвати. То је прави пут који прелазе да би стигли до катарсе за коју Платон вели да означава спајање душе и света. У таквој екстази снаге путника расту као плима која спутане историјом никада неће понети. Они који су напустили тескобу купеа осећају приближавање силне духовне моћи коју Ганга зрачи расута у одблесцима хиљаду зрака које распршују њени таласи да би се сви у души путника спојили у јединство. Када сиђу с воза, они су већ спремни, знају да ће их Ганга ослободити и већ слуте да је почео преображај који ће се довршити клицањем, купањем, спајањем с њеном животном снагом која влада над човеком и над целим светом. У возовима који носе екстатичке путнике, тако различите од разобручених фудбалских навијача чији главни циљ је купање у пастеризованом пиву, видимо усплахирене ходочаснике чија осећања су толико појачана да с лакоћом скачу у други свет који је за навијаче празноверни привид. Вероватно су њихови преци зато и колонизовали Индију да би је извели из заосталог привида слободе у стварност Источно индијске компаније и њених модерних деривата. Слично као што су нас у Србији марксисти превезли у свет „реалних односа“ по цену уништења екстатичног сна о царству небеском, које је по њиховом просвећеном мишљењу ван сваке сумње празноверно, застарело и превазиђено. Требало је то још практично доказати рушењем цркава, у чему су их наследили Шиптари, најбољи следбеници комунистичког нихилизма или, како би Карл Маркс рекао, критике свега постојећег. 
Комунисти су ратовали чак и с етеричним русалкама које су у источној Србији хапсили док су падале у нереални и ненаучни ритуални транс повезивања с другим светом. Чинили су то да се не би видело колико је, у поређењу с тим, њихов транс обећане бескласне и бесквасне земље лоше одглумљен. Комунизам овде помињемо као врхунац просвећености настале јаловим укрштањем енглеског емпиризма и немачког идеализма. У Индији, са великог растојања, није тешко видети идентитет емпиризма и идеализма, као и њихових каолибералних травестија. Њихов заједнички циљ је стварање света без екстазе, најдосаднијег од свих светова и његово разарање техно логиком. У зачараним земљама емпиризма и идеализма сваки путник има своје посебно седиште и не меша се с другим путницима, а с боговима још мање јер су возови само возови, а машине само машине. Они само мењају место и то је све. Када се међу емпиристичким и идеалистичким народима и распири неко узбуђење, онда је то рат и ништа више, јер је рат њихов смисао за екстазу. „Волећете мир као средство за нове ратове - а кратак мир више од дугог... Кажете да је добар повод који чак и рат чини светим? А ја кажем вама: добар је онај рат који сваки повод чини светим. ${ }^{\text {"5 }}$ За друго осим рата просветитељи су тешко способни јер обожавају историју као Бога. Никада нису били и никада неће бити у стању да виде да Бог није историја, да путовање није еволуција или развој, како они воле да мисле да би дали легитимитет илузијама, јер се само лаж усавршава: чим истину почнемо да усавршавамо, она постаје лаж.

Напуштајући композицију просвећене историје нама је довољно да закључимо да излазак на кров воза никако није последица пренатрпаности купеа. Он има вредност по себи као прави егзодус, бекство у слободу, обећана земља због које није потребно прећи пустињу јер је као „екстатичка метафора“ сасвим близу нас. Псеудо Лонгин у делу De

5 Фридрих Ниче, Тако је іоворио Зарайустира, Ризница, Београд 2010 , стр. 34 
sublimitate (О узвишеном) описује како је читалац узнесен када путујући кроз текст наиђе на праве речи. Он се тада пење до смисла сублимног које је, како већ каже латинска реч, састављено од sub (испод) и $\lim$ (горња греда на вратима). Ако се неко уздигао до врха пролаза, попео до крова врата, он ће и проћи тамо где треба. На једном путовању возом кроз планинске пределе државе Асам, кроз дивљу лепоту шума и гребена, у полупразном возу путници су напуштали своја седишта и пели се на кров да би се узнели до самог догађаја, да не би емпиријски посматрали свет кроз идеализована окна. Били су то млађи људи и нико их у томе није спутавао јер је то опасно или недозвољено. Слобода је заправо неупредиво мање опасна од страха да се напусте ограђени простори. Права опасност је не изаћи, остати заувек у тескоби. Индијска железница то зна, као и сами возови, на које се просвећено гледа као на обичне објекте, jep су, пуни одушевљења, унутар у основи трансценденталне индијске културе попримили другачију димензију и преобразили се у својеврсне субјекте ослобођења. Као што је у древној филозофији тело возило душе, тако је и у индијском свету воз превозник и средство путовања у други свет, припрема за прави пут. Одуховљење машине је почетак ослобађања историје и делотворно антиколонијално средство. Тако је и индијска железница дала и даје свој обол напуштању индустријског колонијалног емпиризма. Величина индијске културе је што свему може да удахне душу. Како модерни човек одавно нема своје дионизијске свечаности и сатурналије, он то не може да осети и та му се слобода чини као пуки проблем транспорта. Али упркос томе индијска железница постојано носи екстатичну поруку егзодуса. 


\section{Литература}

Andrew, W. P. (1884) Indian Railways. London: W H Allen.

Андрић Иво (2010) Приче о особењащима и малим људима. „Злостављање“. Београд: Лагуна.

Awasthi, A. (1994) History and Development of Railways in India, New Delhi: Deep and Deep Publications.

Bhandari, R. R. (2006) Indian railways: Glorious 150 Years (2nd ed.). New Delhi: Publications Division, Ministry of Information \& Broadcasting, Govt. of India..

Ghosh, S. (2002) Railways in India - A Legend. Kolkata: Jogemaya Prokashani.

Hurd, John; Kerr, Ian J. (2012) India's Railway History: A Research Handbook, „Handbook of Oriental Studies“. Section 2, South Asia, 27. Leiden; Boston: Brill.

Huddleston, George (1906) History of the East Indian Railway, Calcutta: Thacker, Spinkand Co.

Петровић, Александар (2014) Асам као ойлеgао йоgељеной

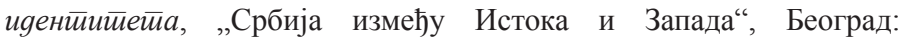
Филолошки факултет.

Petrovic, Aleksandar (2015) On the Cattle of Helios and God's Dumb Creation: An outsider's review of the culture of India based on personal experience compared with the European and American dream, "Modern Research Studies", vol. 2 iss.3, Agartala: Indian National Institute of Technology. 


\section{Prof. Aleksandar Petrović, PhD University of Belgrade Faculty of Philology}

\section{EXODUS TO ROOF}

Indian railways as an ecstatic metaphor of freedom

\section{Summary}

Railway that across the predestined track goes towards the final goal is one of the symbols of enlightened history power. But in the Indian culture railway takes meanings that transcend representation of rapid progress and movement towards a certain goal. Images of crowded composition are a common chimera of Indian railways where the general prejudices are caught in the media cobwebs. These scenes of crowds of people on rooftops, while an equal number in bunches hang on the hips, really do exist, but they are mostly part of an endless number of feasts when the excited inhabitants haul down from the periphery to the center of the celebration. As a modern man doesn't have his Dionysian festivities and Saturnalia, but only surrogates of the society of the spectacle, he cannot feel that exeperience, and the freedom seems to him as a mere problem of transport. It is about the transport (Greek - $\mu \varepsilon \tau \alpha \varphi \rho \rho \alpha ́)$, not towards some particular place, but towards the world of freedom. Rail thus carries message of ecstatic transition.

Key words: Indian Railways, freedom, metaphor, ecstasy, steam machine. 